\title{
Pre-agricultural plant management in the uplands of the central Zagros: the archaeobotanical evidence from Sheikh-e Abad
}

Article

Accepted Version

Whitlam, J., Bogaard, A., Matthews, R., Matthews, W., Mohammadifar, Y., Ilkhani, H. and Charles, M. (2018) Preagricultural plant management in the uplands of the central Zagros: the archaeobotanical evidence from Sheikh-e Abad. Vegetation History and Archaeobotany, 27 (6). pp. 817-831. ISSN 0939-6314 doi: https://doi.org/10.1007/s00334-0180675-x Available at https://centaur.reading.ac.uk/68880/

It is advisable to refer to the publisher's version if you intend to cite from the work. See Guidance on citing.

To link to this article DOI: http://dx.doi.org/10.1007/s00334-018-0675-x

Publisher: Springer

All outputs in CentAUR are protected by Intellectual Property Rights law, including copyright law. Copyright and IPR is retained by the creators or other copyright holders. Terms and conditions for use of this material are defined in the End User Agreement. 


\section{www.reading.ac.uk/centaur}

\section{CentAUR}

Central Archive at the University of Reading

Reading's research outputs online 
a)

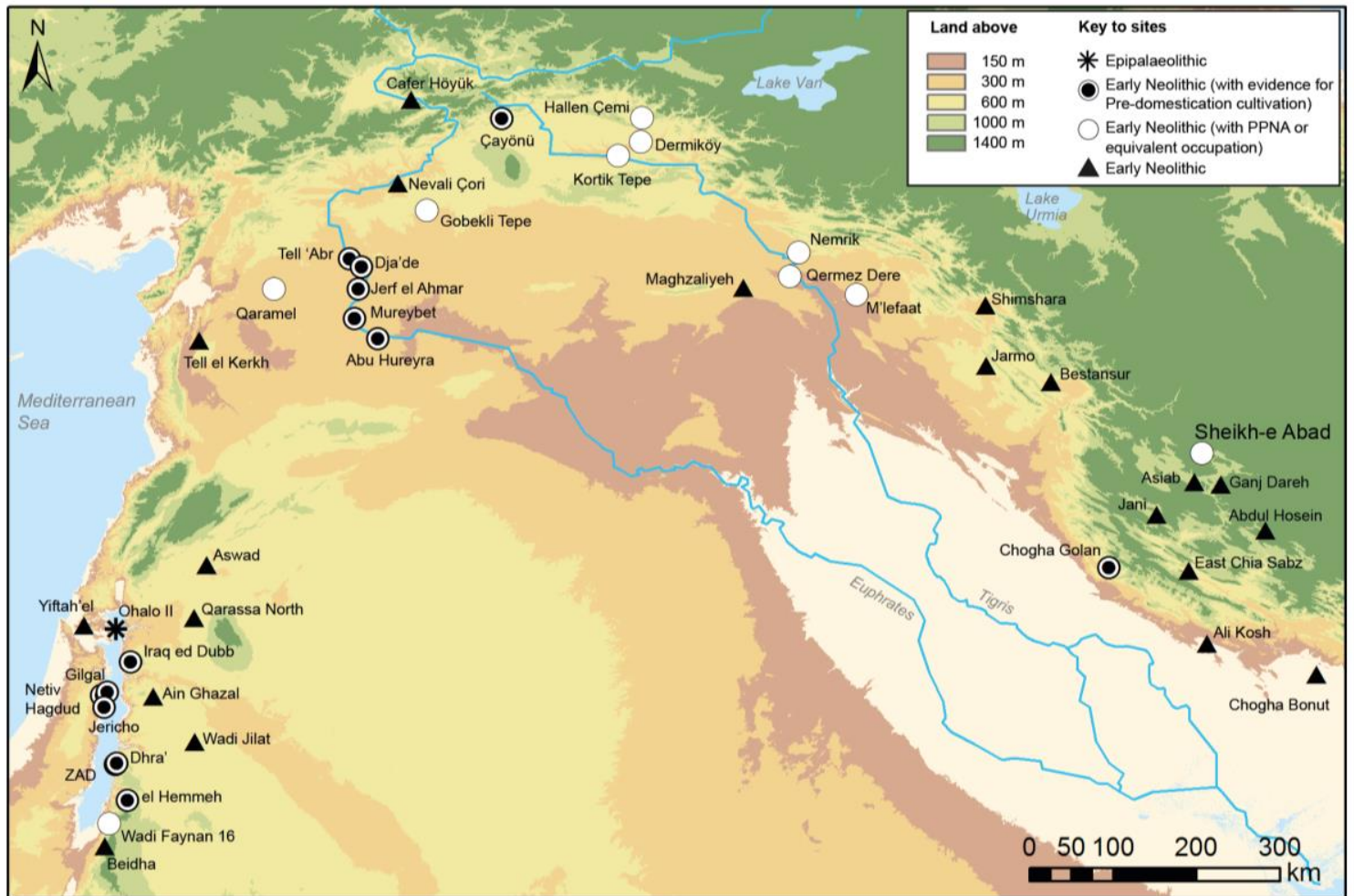

b)

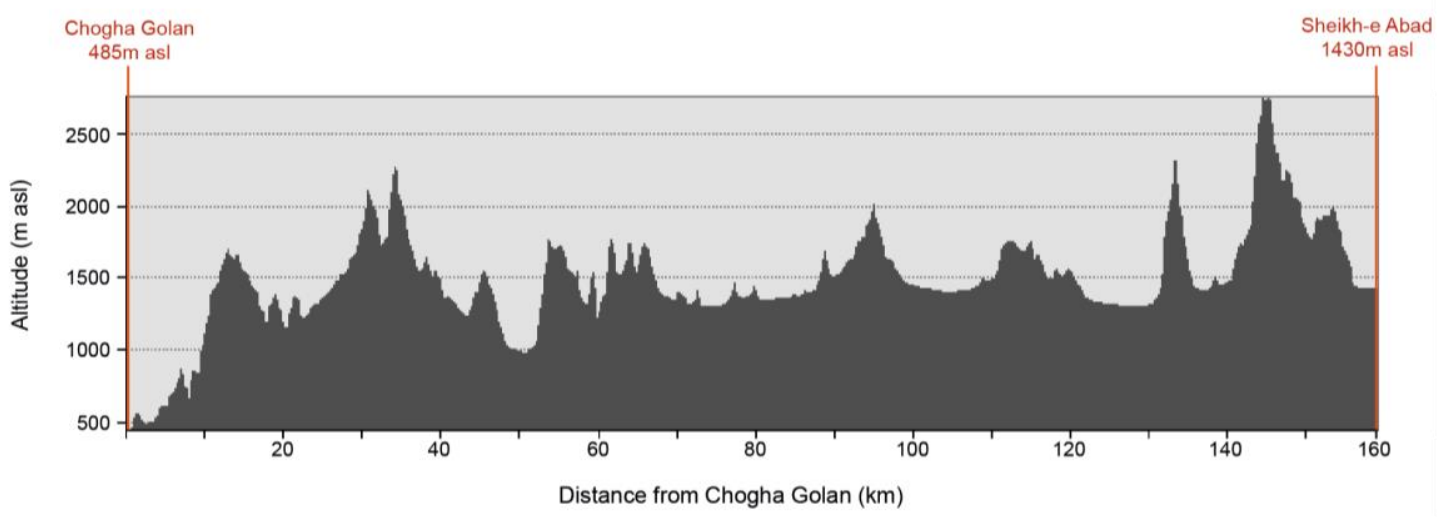



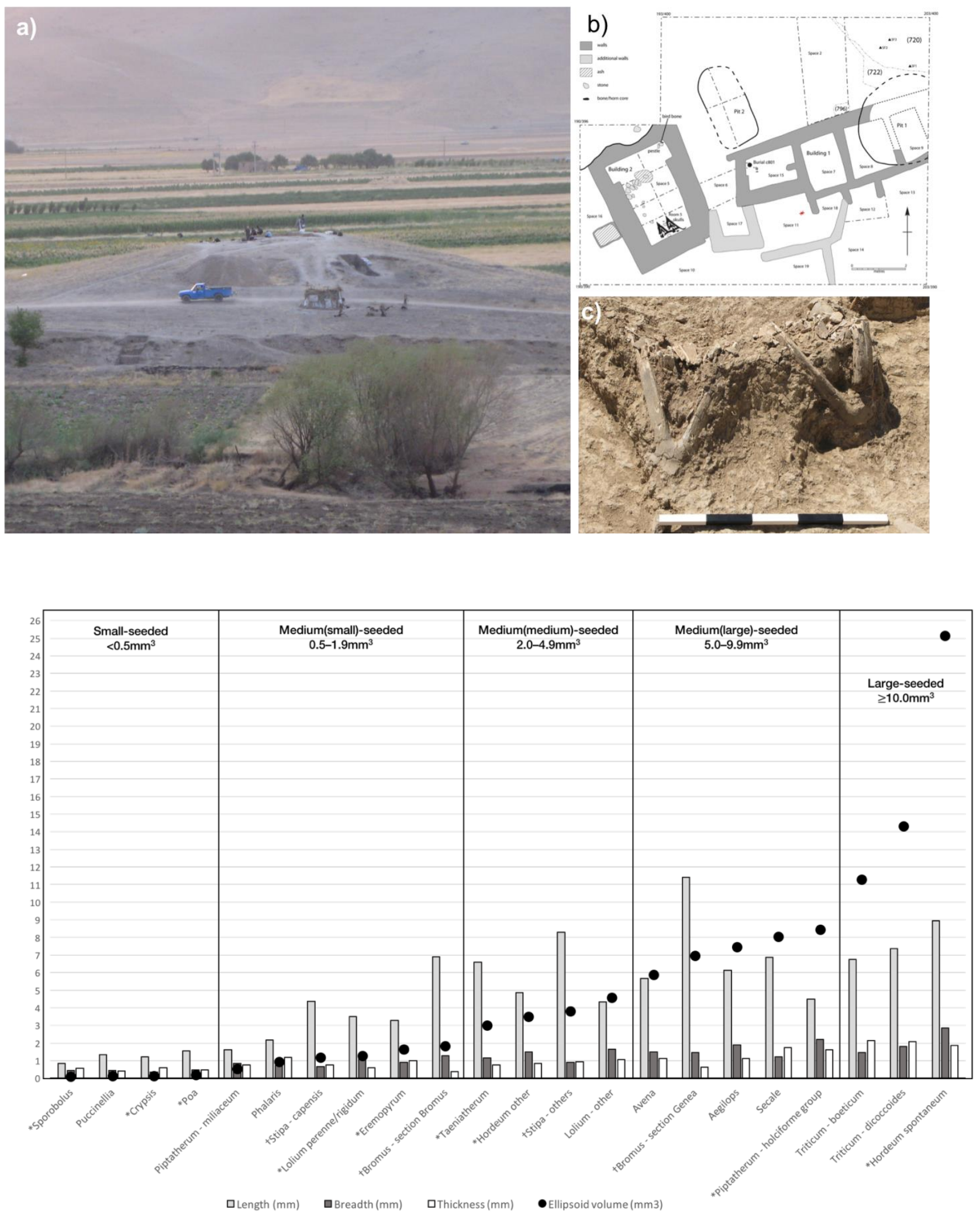


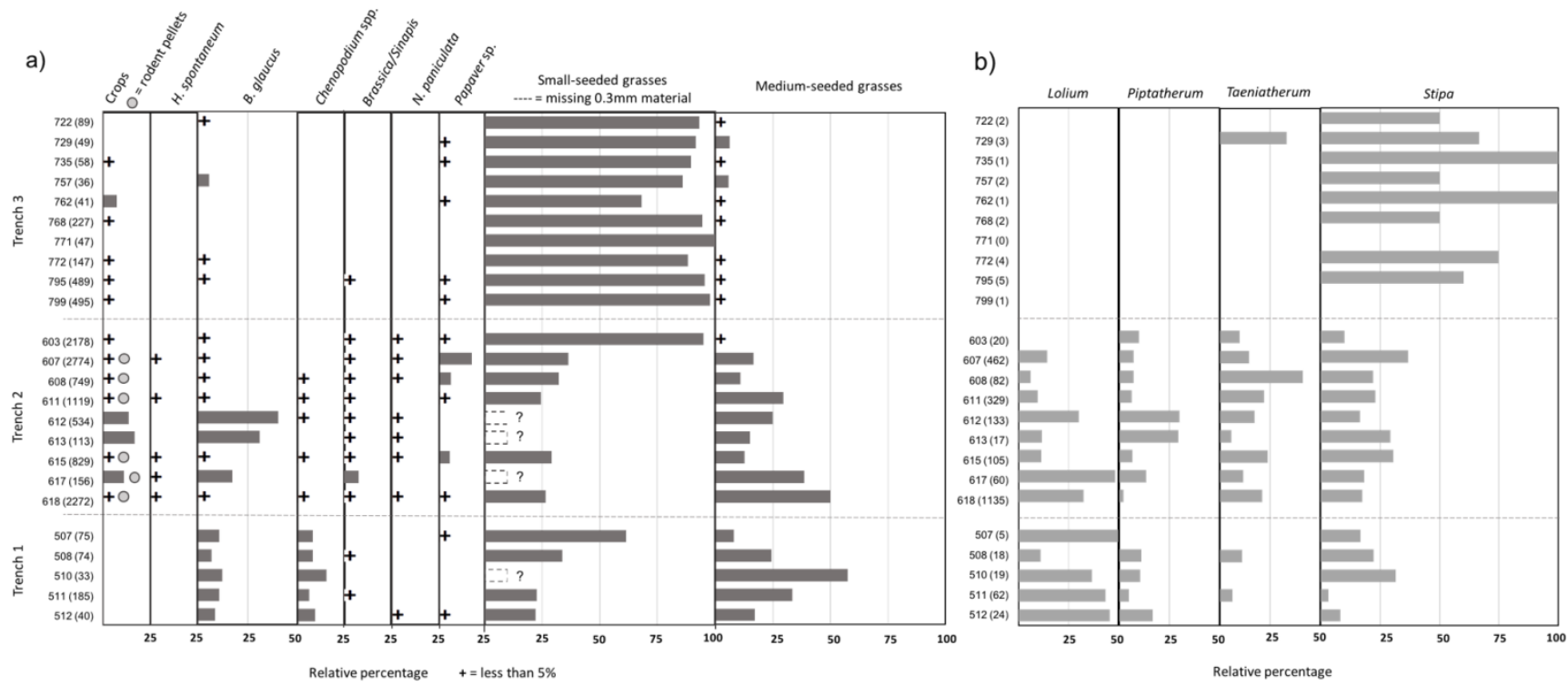

a)

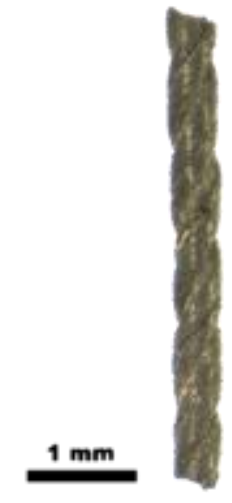

c)

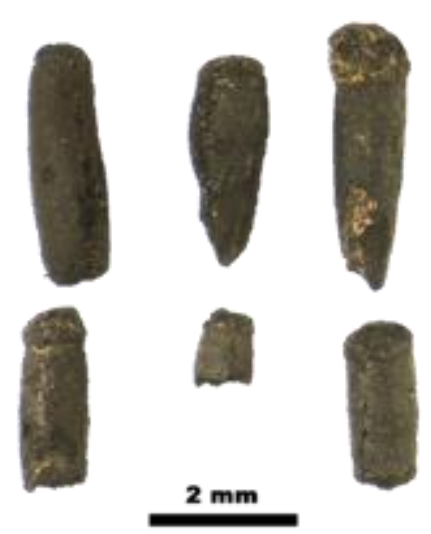

b)

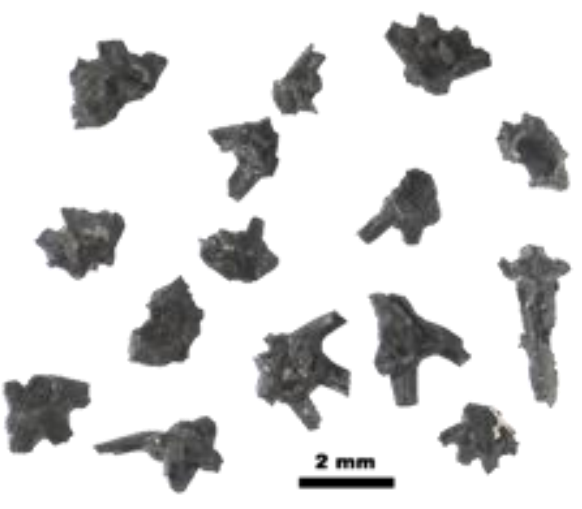

d)

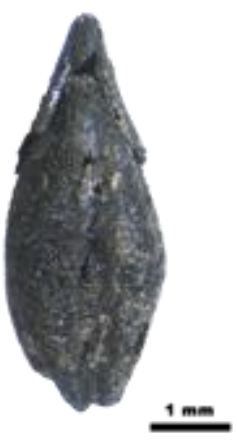




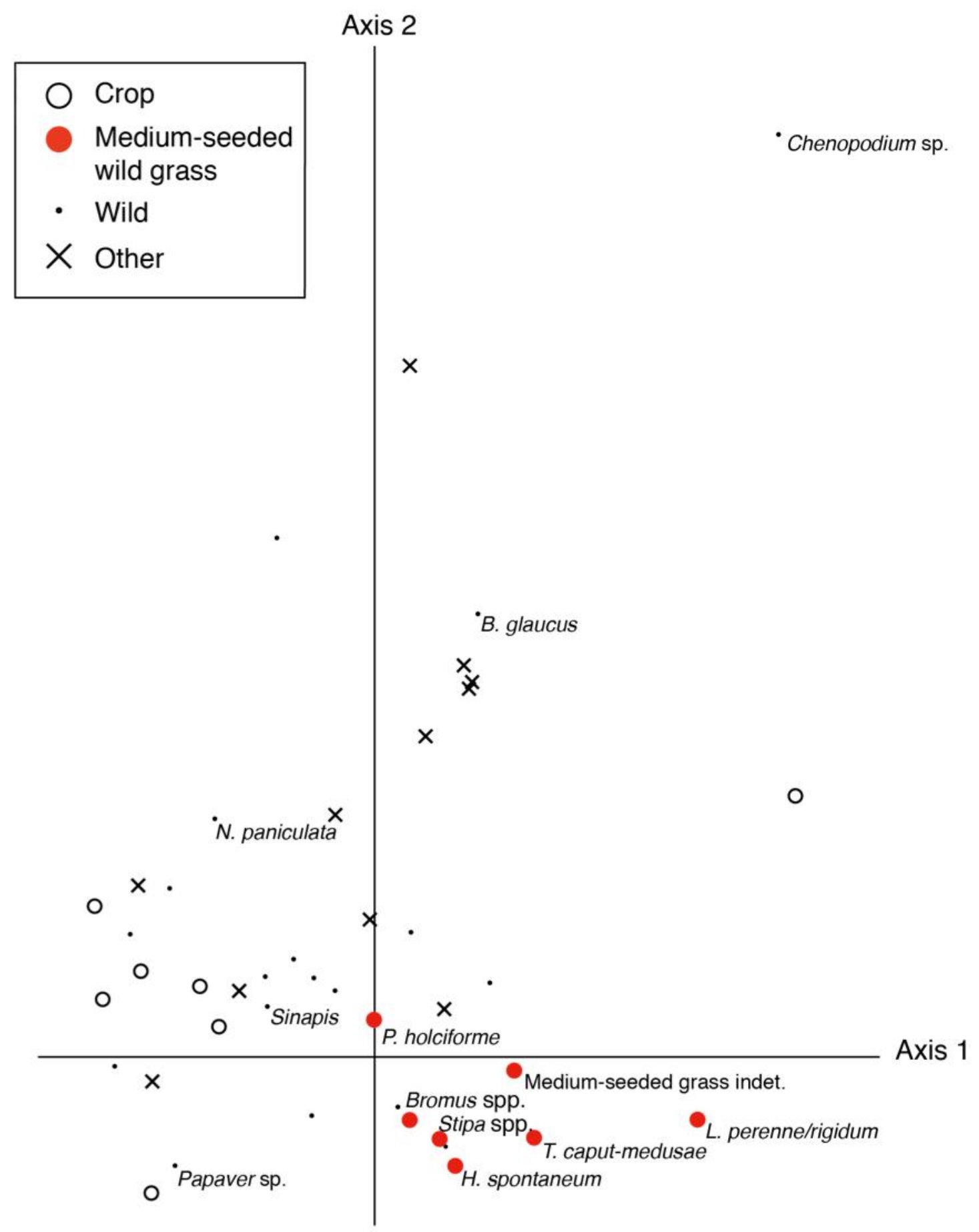

